\title{
Determination Of Form (Shape) Stability Performance On Curved Laminated Wood (Lvl) Elements
}

\author{
Necmi Kahraman ${ }^{1}$, Mustafa Altınok ${ }^{2}$ \\ ${ }^{1}$ Afyon Kocatepe University, Faculty of Fine Arts, Interior Architecture and Environmental Design, Afyonkarahisar \\ ${ }^{2}$ Gazi University, Faculty of Technology, Department of Wood Products Industrial Engineering, Ankara. \\ e-posta:nkahraman@aku.edu.tr
}

Geliş Tarihi: 13.02.2017 ; Kabul Tarihi: 22.11.2017

\begin{tabular}{cl} 
& Abstract \\
\cline { 2 - 3 } $\begin{array}{c}\text { Keywords } \\
\text { Vacuum Membrane }\end{array}$ & $\begin{array}{l}\text { The following determines performance stability of curved laminated wood elements made with a } \\
\text { vacuum membrane press. For this purpose, } 13 \text { layers of } 1.5 \mathrm{~mm} \text { thick beech (Fagus orientalis Lipsky), } \\
\text { Presses, Laminated } \\
\text { Wood }\end{array}$ \\
$\begin{array}{l}\text { sessile oak (Quercus petrean Liebl) and pine (Pinus sylvestris) veneer layers were glued with D4 } \\
\text { adhesive using a vacuum membrane press and curved laminated wood samples were prepared. } \\
\text { Diagonal compression test was applied on the prepared samples. The highest diagonal compression } \\
\text { strength difference found between beech laminate and oak laminate was statistically insignificant. } \\
\text { Most low strength samples consisted of laminated pine. }\end{array}$ \\
\hline
\end{tabular}

\section{Kavisli Ahşap Lamine Elemanlarda Biçim (Form) Kararlılığı Performansının Belirlenmesi}

\begin{abstract}
Özet
Bu çalışmada, vakumlu membran preste üretilmiş kavisli ahşap lamine elemanların biçim (form) kararlılığı performanslarının belirlenmesi amaçlanmıştır. Bu amaca uygun olarak 1,5 mm kalınlığında

Doğu kayını (Fagus orientalis Lipsky), sapsız meşe (Quercus petrean Lieble) ve sarıçam (Pinus sylvestris) papel kaplamalar, PVAc dispersiyonu D4 tutkalı ile vakumlu membran preste yapıştırılarak 13 katmandan oluşan kavisli lamine ahşap örnekler hazırlanmıştır. Hazırlanan numunelere diyagonal basma direnci deneyi uygulanmıştır. Sonuç olarak, diyagonal basınç direnci en yüksek kayın laminasyonda çıkarken meşe laminasyon ile arasındaki fark istatistiksel olarak önemsiz çıkmıştır. En düşük direnç değerini sarıçam laminasyon örnekler vermiştir.
\end{abstract}

Anahtar Kelimeler

Vakumlu Membran

Pres, Lamine Ahşap
(C) Afyon Kocatepe Üniversitesi

\section{Introduction}

Compared to other composite materials (woodbased boards), laminated wood is preferred as it demonstrates strong similarity to wood and has forming-flexibility. Laminated materials are widely used as columns, beams, arches, molding, and various building elements, such as brackets and in furniture manufacturing. In particular, the use of laminated material in curved furniture elements are more technical, aesthetic and economical and offer several advantages in terms of ease in production.

It is stated that laminated wood is formed from wooden panels handled by cutting, peeling and trimming techniques, then the layers are glued hot or cold pressing flat in a mould. The wood fiber are parallel to each other and to the axis of the length between the elements, (TS EN 387, 2003).

With laminated wood, wood waste can be avoided, with homogeneous layer regulation and pres could be obtain desired building or furniture elements. Laminated wood allow with the help of large column-free spans and can be safely crossed, (Colling, 1995).

Laminated Veneer Lumber (LVL) has superior value, technological properties, and aesthetic qualities and it is more economic than solid woods. It can be used 
in the manufacture of such as furniture, cupboard, desk, chair, table and so on (Eckelman 1993).

According to the deformation analysis results of curved laminated wood structural members by loading and unloading when the installation of wood type and time periods of deformation were not effective. $11 \mathrm{~mm}$ of elastic deformation and 4 $\mathrm{mm}$ of plastic deformation in the examples have been identified within the specified period of deformation (fatigue) were not increase (Altınok et al. 2008).

To determine the bonding performance in laminated wooden elements produced with a vacuum membranne press, with $1,5 \mathrm{~mm}$ thickness beech, oak and pine papel veneers pressed in 13 layers by using PVAC D4 adhesive were prepared. Parallel and vertical adhesion strength tests were applied to the samples. The highest parallel adhesion strength was obtained in oak, the lowest in pine and the highest vertical adhesion was obtained in beech, the lowest in pine samples (Altınok, 2009).

Parallel to the fibers and the counter directional 3 layers, static bending resistance of laminated samples that were prepared from 5 wood types was investigated in this study. As a result of this study it was stated that the modulus of elasticity, tear resistance is proportional to the voltage limitation and perpendicular to fibers, increases counterlamination and decreases the density of the material which determined to continue this increasing (Park et al. 2003).

Glued with Klebit 303, 305.0 and Super Lackleim 308 KLEIBERIT the beech, oak and pine wood with the highest order of resistance of fibers parallel to the bonding adhesive used Klebit 303 beech and oak, and lowest in use of super glue Lackleim 308303 Klebit used glue were mentioned (Örs et al.1999).

PVAc-D3 strengthened with the addition of 5\% hardener two component PVAc-D4 and polyurethane adhesive with glued acacia, pear, chestnut, sessile oak, fibers parallel to the bonding strength and Taurus cedar wooden prepared samples, the highest-D4 PVAc glue with the acacia $\left(14.418 \mathrm{~N} / \mathrm{A} \mathrm{mm}^{2}\right)$, the lowest in the PVAc-D3 with glue Taurus cedar $\left(6.249 \mathrm{~N} / \mathrm{mm}^{2}\right)$ has been reported (Söğütlü and Döngel, 2007).

To determine the effects of open-air conditions on the performance of laminated elements, fir wood and glue with phenol-resorsin solid-solid, veneersolid laminating and veneer-veneer combinations of elements were prepared according to the principle. As a result of the experiments, the shear and tensile resistance in the direction perpendicular to glue line is the most high-solid-solid samples, water samples kept in the most solid-solid samples in resistance takes place, solid-solid samples of shear resistance showed more than $44 \%$ compared to according veneer-veneer samples was determined (Leufenberg, 1982).

Study investigating to the effect of the mechanical properties of Alder lamination process, the layer thickness of $2 \mathrm{~mm}$ thick layer of laminated specimens are more resistant than the layer thickness of $4 \mathrm{~mm}$ laminated samples, fibers parallel to the pressure, shear parallel to the fibers, fibers perpendicular to the bending modulus of elasticity resistance are higher on the samples with PVAc glue, fibers perpendicular to tensile splitting strength and screw holding ability of polyurethane glue in the samples were found to be higher (Kılıç and Gürey, 1996).

This study of laminated wood type examined the number of layers of glue and the effects of cultivar strength to bending. As a result of the study, the 7layer samples, respectively, the highest bending strength of beech, pine and oak laminated materials have shown the highest bending strength (Altınok and Döngel, 1999).

The technological properties of wood material with 4 layers laminated with PVAc-D4 adhesive from 5 $\mathrm{mm}$ thick Taurus sedge, yellow peach, Oriental beech and stemless oak veneers were superior to massive wood materials representing these tree species. (Keskin, 2001). 
Oriental Beech and Black Poplar were prepared with a combination of 5-layer laminated specimens (glued with PVAc-D4 glue) air-dry density of 0.571 $\mathrm{g} / \mathrm{cm}^{3}$, bending strength $98.66 \mathrm{~N} / \mathrm{mm}^{2}$, flexural modulus of elasticity of $9020.24 \mathrm{~N} / \mathrm{mm}^{2}$, compression strength $54,49 \mathrm{~N} / \mathrm{mm}^{2}$, shear strength $9.11 \mathrm{~N} / \mathrm{mm}^{2}$ and the cleavage strength is determined as $0.540 \mathrm{~N} / \mathrm{mm}^{2}$ (Keskin and Togay, 2003).

Shaped laminated wood components with Radio Frequency (RF) presses are widely used in wooden laminated furniture elements. However, the use of RF presses, hazardous to human health and the environment as known (Genbilim, 2007). Double sided patterns are also needed for them and doublesided mold making is a very sensitive, very difficult and costly task. In case the mold and the conjugate are not compatible, the mold affects the quality of the product adversely. This study aimed to determine production capabilities and some mechanical performance by encouraging the usage of vacuum membrane presses which eliminates the above mentioned disadvantages.

\section{Material and Method}

\subsection{Papel veneer}

In laminated veneer which has $1.5 \mathrm{~mm}$ thickness and $8-10 \%$ moisture content up to the amount of dried, beech (Fagus orientalis Lipsky), oak (Quercus petrean Liebl) and pine (Pinus sylvestris) were used. Papel veneers were obtained with a random type of purchase. In papel veneer was given special care by production of the excellent wooden materials with smooth fiber.

\subsection{Glue}

The samples were glued with $5 \%$ of hardening adhesive (Turbo Hardener 303.5) and reinforced with two-component polyvinyl acetate (PVAC-D4) glue. PVAC-D4 increased resistance to moisture, according to BS EN 204 glue that brought the quality of adhesion D4 (Söğütlü and Döngel 2007). The manufacturer gave the following technical characteristics of the glue as density $\sim 1.12 \mathrm{~g} / \mathrm{cm}^{3}$, viscosity (20 ㅇ) $13000 \pm 2000 \mathrm{mPas}, \mathrm{pH} \sim 3$, the gelling time of 6-10 min., frost resistance $-300 \stackrel{\circ}{ }{ }^{\circ}$, the amount of $180-200 \mathrm{~g} / \mathrm{m}^{2}$, mode of application by brush or roller riding machine, storage duration

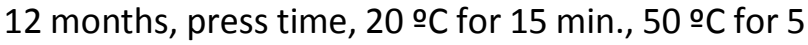
min., and $80 \stackrel{\circ}{\circ}$ for $2 \mathrm{~min}$. (Kleiberit, 2006).

\subsection{Preparation of Test Specimens}

Papel veneers were allowed to reach equilibrium humidity at $20 \pm 2{ }^{\circ} \mathrm{C}$ temperature and $65 \pm 5 \%$ relative humidity conditions in a ventilated and nondirect sunlight environment. According to TS EN 322 , the average amount of moisture in the preliminary control was \% $12 \pm 0,5$ in 20 randomly selected samples. In the preparation of the test specimens, the fiber directions from the papel veneers were formed 13 layers parallel to each other and glue was applied to the layer surfaces. In the gluing of layers; the glue solution was applied to one of the surfaces with a glue application roller so that it would be $180-200 \mathrm{~g} / \mathrm{m} 2$, and is pressed in the membrane press. Pressing duration is 20 minutes, press temperature is set at $80{ }^{\circ} \mathrm{C}$. The draft samples were stored until reaching the constant weight in the air conditioning cabinet with a temperature of $20 \pm 2$ ㄷ and relative humidity of $\% 65 \pm 5$ according to BS EN 204 (2001) before the experiments.

Moreover curve lower limit of the production of curved laminated element was determined by preparing molds having curves in four different radious $(40,60,80$ and $100 \mathrm{~mm})$. Test samples were prepared by cutting the standard sizes. 3 wood types, 3 widths and 5 radius of samples prepared with 10 units to 450 units (Fig. 1).
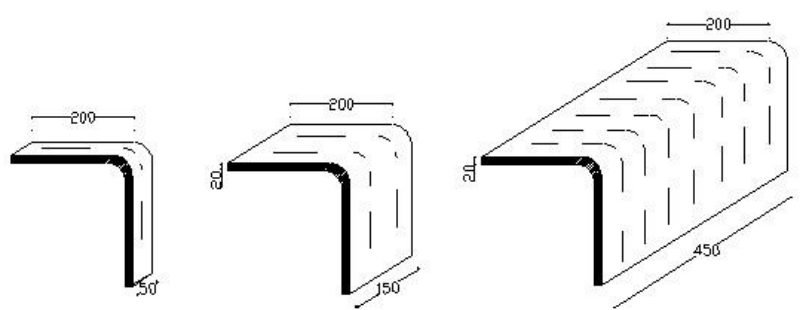

Fig. 1 Three test samples of different widths

\subsection{Method}

The diagonal compression test was applied to the test samples with of 5 tonnes 'of universal tester' and with static loading which enabled $2 \mathrm{~mm} / \mathrm{min}$. 
speed at pressure column (Fig.2). The diagonal compressive strength $(\mathrm{Mb})$ was calculated by the formula below (Fig.2). The test applied according to ASTM D4761 (2013).

$$
\begin{aligned}
& M_{b}=F_{\max b} \times L_{b} \\
& \mathrm{Mb}=\text { Moment }(\mathrm{Nm}) \\
& \text { Fmaxb }=\text { Maximum force } \\
& \text { at the time of fracture }(\mathrm{N}) \\
& \mathrm{Lb} \quad=\text { Moment arm }(\mathrm{m})
\end{aligned}
$$

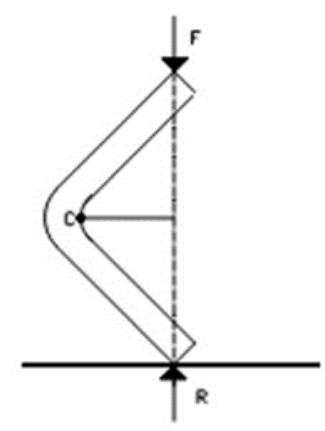

Fig. 2 Diagonal compression test

\begin{tabular}{|c|c|c|c|c|c|c|c|}
\hline \multirow{3}{*}{$\begin{array}{c}\text { Radius } \\
(\mathbf{m m})\end{array}$} & \multirow{3}{*}{$\begin{array}{l}\text { Width } \\
\text { (mm) }\end{array}$} & \multicolumn{6}{|c|}{ Wood Type Diagonal Compressive Strengths $\left(\mathrm{N} / \mathrm{mm}^{2}\right)$} \\
\hline & & \multicolumn{2}{|c|}{ Beech } & \multicolumn{2}{|c|}{ Oak } & \multicolumn{2}{|c|}{ Pine } \\
\hline & & DCS $^{1}$ & $\mathbf{S}$ & DCS $^{1}$ & $\mathbf{S}$ & DCS $^{1}$ & $\mathbf{S}$ \\
\hline \multirow{3}{*}{40} & 50 & 61,12 & 8,53 & 62,72 & 9,31 & 37,12 & 2,26 \\
\hline & 150 & 63,36 & 9,65 & 59,15 & 2,44 & $32,75^{* *}$ & 4,37 \\
\hline & 450 & 67,25 & 6,51 & 64,29 & 3,96 & 39,84 & 6,79 \\
\hline \multirow{3}{*}{60} & 50 & 63,21 & 6,31 & 61,54 & 5,95 & 43,99 & 3,14 \\
\hline & 150 & 65,74 & 4,07 & 63,01 & 5,65 & 37,02 & 4,61 \\
\hline & 450 & 71,35 & 4,78 & 68,97 & 5,94 & 46,42 & 5,18 \\
\hline \multirow{3}{*}{80} & 50 & 58,53 & 12,93 & 67,69 & 7,03 & 49,21 & 3,63 \\
\hline & 150 & 65,39 & 4,87 & 64,24 & 3,73 & 51,09 & 10,79 \\
\hline & 450 & 74,39 & 3,94 & 69,47 & 10,46 & 50,92 & 3,47 \\
\hline \multirow{3}{*}{100} & 50 & 65,76 & 2,20 & 64,86 & 1,07 & 53,78 & 3,87 \\
\hline & 150 & 66,17 & 7,80 & 63,31 & 7,02 & 58,59 & 3,18 \\
\hline & 450 & 76,38 & 3,12 & $78,50 *$ & 4,20 & 55,18 & 3,90 \\
\hline
\end{tabular}

\subsection{Evaluation of the data}

Multi-variance analysis was performed to determine the effects of the wood type, curve

Table 1 Average values of diagonal compressive strengths

According to Table 1 the highest strength was with the beech lamination $\left(78.5 \mathrm{~N} / \mathrm{mm}^{2}\right)$ and the lowest strength obtained with the pine lamination (32.75 $\mathrm{N} / \mathrm{mm}^{2}$ ). With the increase in the radius and width of the beech lamination, the strength of element was seen to be thriving. Increasing the overall strength increases as the radius of the curved sessile oak lamination. However, the element would decrease the width of the transition to $150 \mathrm{~mm}$. The Pine lamination strength change curve radius of sessile oak, with 40 and 60 also showed similarity. radius and width difference of curved laminated elements. Mutual interactions of sources of variance $\alpha=0.05$ according to the case of significant differences, which are important factors determined by Duncan's test.

\section{Results}

The average values of diagonal compressive strength are given against wood type, curve radius and width of the formed laminated elements in Table 1. 


\begin{tabular}{lrrrrr}
\hline Source of Variance & Sum of Squares & $\begin{array}{c}\text { Degrees of } \\
\text { Freedom }\end{array}$ & Mean Squares & F Value & P $\leq 0,05$ \\
\hline Wood type & 9399,01 & 2 & 4699,51 & 126,89 & 0,00 \\
Radius & 1649,17 & 3 & 549,72 & 14,84 & 0,00 \\
Width & 895,23 & 2 & 447,61 & 12,08 & 0,00 \\
Wood type x Radius & 689,58 & 6 & 114,93 & 3,10 & 0,01 \\
Wood type x Width & 236,68 & 4 & 59,17 & 1,59 & 0,18 \\
Radius x Width & 81,33 & 6 & 13,55 & 0,36 & 0,90 \\
Wood type x Radius x Width & 404,71 & 12 & 33,72 & 0,91 & 0,54 \\
Eror & 2666,52 & 72 & 37,03 & & \\
\hline Total & 398476,13 & 107 & & & \\
\hline
\end{tabular}

In terms of the diagonal compression strength the effects of wood type, radius, width variables and the interaction between the binary wood type-radius are a significant difference the between groups ( $\alpha=$ 0.05 ). The averages of the diagonal compressive strength at the level of the wood type, radius, width variables and values of the LSR to 0.95 Duncan test comparison results are given in Table 3.

Table 3. The results of the comparative averages of diagonal compression strength at the level of wood type, width and

\begin{tabular}{|c|c|c|c|c|c|c|c|c|}
\hline \multirow{2}{*}{$\begin{array}{l}\text { Wood } \\
\text { type }\end{array}$} & \multicolumn{2}{|c|}{$\begin{array}{l}\text { Diagonal compression } \\
\text { strength }\left(\mathrm{N} / \mathrm{mm}^{2}\right)\end{array}$} & \multirow{2}{*}{$\begin{array}{l}\text { Width } \\
(\mathrm{mm})\end{array}$} & \multicolumn{2}{|c|}{$\begin{array}{l}\text { Diagonal compression } \\
\text { strength }\left(\mathrm{N} / \mathrm{mm}^{2}\right)\end{array}$} & \multirow{2}{*}{$\begin{array}{r}\text { Radius } \\
(\mathrm{mm})\end{array}$} & \multicolumn{2}{|c|}{$\begin{array}{l}\text { Diagonal compression } \\
\text { strength }\left(\mathrm{N} / \mathrm{mm}^{2}\right)\end{array}$} \\
\hline & Xav & HG & & Xav & $\mathrm{HG}$ & & Xav & $\mathrm{HG}$ \\
\hline Beech & 66,55 & A & 50 & 57,46 & B & 40 & 54,17 & $\mathrm{C}$ \\
\hline Oak & 65,64 & A & 150 & 57,48 & B & 60 & 57,91 & B \\
\hline \multirow[t]{2}{*}{ Pine } & 46,32 & B & 450 & 63,58 & A & 80 & 61,21 & B \\
\hline & & & & & & 100 & 64,72 & $\mathrm{~A}$ \\
\hline
\end{tabular}

According to Table 3 at the level of wood type the highest level strength is in the beech $\left(66.55 \mathrm{~N} / \mathrm{mm}^{2}\right)$ and sessile oak and the dual interaction between them are ineffective and scotch pines are recorded with the lowest strength $\left(46.32 \mathrm{~N} / \mathrm{mm}^{2}\right)$. At $450 \mathrm{~mm}$ width at the level of strength to the highest $(63.58$ $\left.\mathrm{N} / \mathrm{mm}^{2}\right)$ and the lowest at $50 \mathrm{~mm}\left(57.46 \mathrm{~N} / \mathrm{mm}^{2}\right)$ and $150 \mathrm{~mm}$, with the minor was found. The high strength level of $100 \mathrm{~mm}$ in radius $\left(64.72 \mathrm{~N} / \mathrm{mm}^{2}\right)$ and the low strength of $40 \mathrm{~mm}\left(54.17 \mathrm{~N} / \mathrm{mm}^{2}\right)$ are found.

The wood type-radius of the test samples of the binary interactions of the effects of diagonal compression strength of the diagonal averages and Duncan test results of the comparison are given in Table 4.

Table 4. The wood type-radius of the binary interactions and the Duncan test results of the comparison

\begin{tabular}{ccccccc}
\hline \multirow{2}{*}{ Radius (mm) } & \multicolumn{7}{c}{ Wood Type Diagonal compression strength $\left(\mathrm{N} / \mathrm{mm}^{2}\right)$} \\
\cline { 2 - 7 } & \multicolumn{2}{c}{ Beech } & Xak & HG & Pave & HG \\
\hline 40 & 63,91 & AB & 62,05 & BC & 36,57 & E \\
60 & 66,76 & AB & 64,51 & AB & 42,48 & E \\
80 & 66,11 & AB & 67,13 & AB & 50,41 & D \\
100 & 69,44 & A & 68,89 & AB & 55,85 & CD \\
\hline
\end{tabular}


beech and sessile oak, the difference between the minor was found. Scotch pine was the lowest with 40 and $60 \mathrm{~mm}$ radius. Effects of wood type at the level of pressure and radius of the diagonal are given in Fig. 3 graphically.

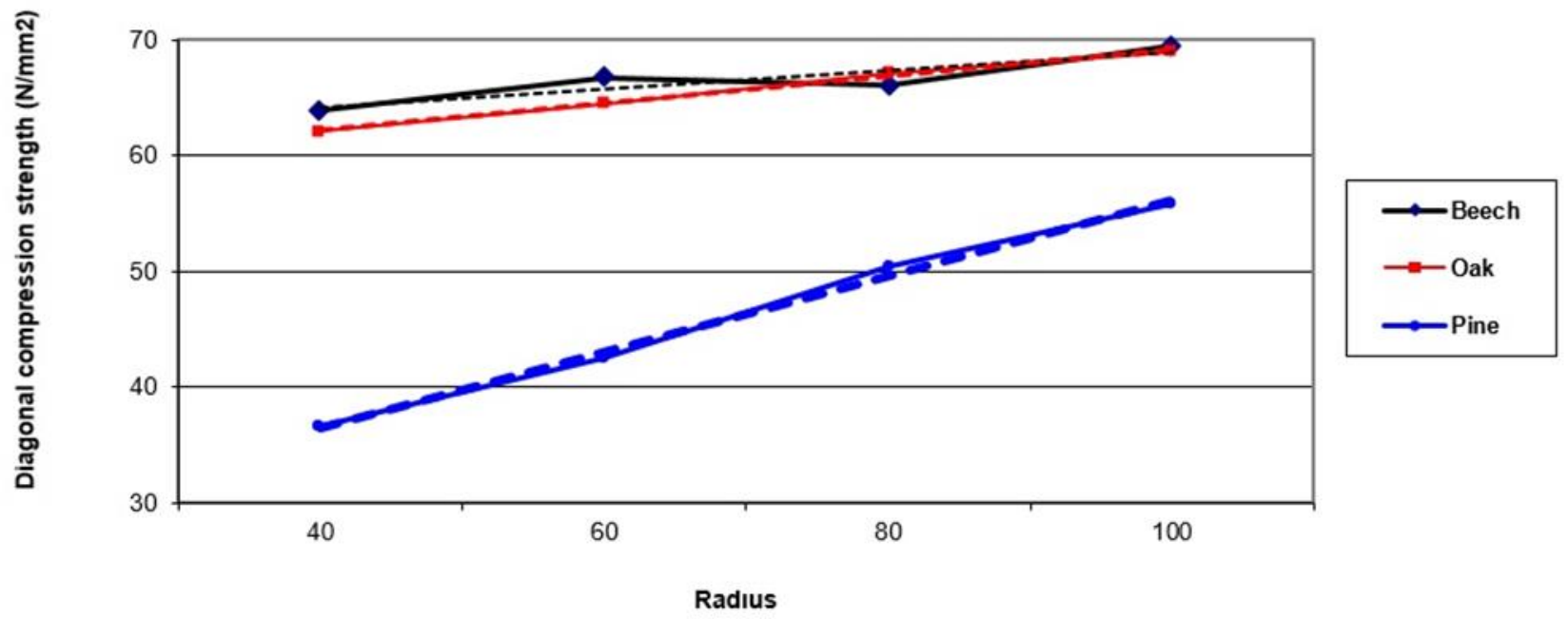

Fig. 3 At the level of the radius the effect of wood type to diagonal compression strength

Table 5. The relationship between the radius, width, wood type variables and diagonal compression strength and on the shaped laminated elements

\begin{tabular}{llrrr}
\hline Variables & & Radius & Width & Wood type \\
\hline Strength $\left(\mathrm{N} / \mathrm{mm}^{2}\right)$ & Radius & 1,00 & $-0,08$ & 0,35 \\
& Width & $-0,08$ & 1,00 & 0,21 \\
& Wood type & 0,35 & 0,21 & 1,00 \\
\hline
\end{tabular}

According to correlation analysis (Table 5); to the diagonal compression strength the highest linear relationships with rate of 0.354 between curve wood type, the lowest linear relationship with rate of 0.082 between curves - widths were observed.

\section{Discussions and Conclusions}

The diagonal compression strength, the effect of wood type and width, wood type-width binary interaction terms were significant statistically. At the level of wood type strength of beech samples were higher and between their strength and oak the difference of strength was negligible. The other two wood types Scots pine strength of the samples was approximately $50 \%$ lower.

Radius and width of the samples increases, the strength of beech experiment also was seen as increasing. As resistance increases, increasing the overall radius of oak samples width of $50 \mathrm{~mm}$ to 150 $\mathrm{mm}$, but decreased strength to the transition. On the Scotch pine lamination the radius of 40 and 60 samples were similar the strength change with oak lamination.

Correlation analysis; between strength with wood type radius width the highest linear correlation with the ratio of 0.35 between radius-wood type, the lowest linear relationship ratio of 0.08 between the radius of - the width were obtained.

Convex and concave, with two different test pieces made of mold, but the concave curved inner parts of the membrane during vacuum pressure to provide the desired die pattern produced for the concave curved adhesion test samples were of poor quality.

For this reason, only by the convex curved molds produced draft samples were used in the study.

In parallel with the results obtained in this study, Uysal (2005) applied the dowel resistance test to lamine wood materials and obtained the best resistance values in the beech samples. In various researches, the best results in the production of laminated wood as well as in the production of all 
kinds of timber production in PVAc applied applications, as known in the literature and in practical applications, have been obtained in beech. In addition, as a deterioration factor of adhesion quality, the surface smoothness of the oak may also be effective. Sönmez (2005) concluded that in the study the highest surface roughness after planing of surface roughness detection was found in oak specimens.

\section{References}

Altınok M, Söğütlü C, Kahraman N,. 2009. Determination of bonding performance of laminated veneer elements produced in vacumm membrane press, Afyon Kocatepe University Journal of Science, Afyonkarahisar, 9(1), 51-60.

Altınok M, Burdurlu E, Özkaya K,, 2008. Deformation analysis of curved laminated structural wood elements, Construction and Building Materials, 22, 32767.

Altınok M, Döngel N., 1999. The effects of wood species, glue type and number of layer in lamination on the bending strength, Z.K.Ü. Karabuk Tec. Edu. Fac. Technology Journal, 2(1-2), 225-237.

ASTM D4761 - 13, 2013. Standard Test Methods for Mechanical Properties of Lumber and Wood-Base Structural Material, United States Standards, USA.

BS EN 204, 2001. Non-structural adhesives for joining of wood and derived timber products, British Standards, England.

Colling F., 1995. Glued laminated timber - Production and strength classes, Step A8.

Eckelman C A., 1993. Potential uses of laminated veneer lumber in furniture, Forest Products Journal, 43, 1924.

Genbilim, Türkiye's Science Webpage, 2011. Losses of electromagnetic fields. http://www.genbilim. com/content/view/1897/36
As a result, in the production of shaped laminated furniture elements from papel veneers; As an alternative to the RF press devices that is harmful to the health with high frequency, double sided mold necessity, reflecting the mold error to the product and high mold costs, vacuum membrane press can be suggested that there is no risk of health risks and could be used with unaccompanied mold (single mold). And as material the beech can be suggested in first place. It may be advisable to consider this situation in practice.

Glued Wood Products, 2002. (Working Group 2), Transportation Research Board. National Academy of Sciences, 2nd Edition, Washington D C, 65-69.

Keskin H., 2001. Technical properties of laminated wood materials and possibilities of using them in woodworking industry, Ph.D. Thesis, Gazi University Institute of Science and Technology, Ankara, 163.

Keskin H, Togay A., 2003. Some physical and mechanical properties of wood laminated materials produced with a combination of the Oriental Beech and Black poplar, Süleyman Demirel University Journal of the Faculty of Forestry, Isparta, 2, 101-114.

Kılıç Y, Gürey A., 1996. The effect of lamination technics on Alder wood's mechanical properties, I. National Furniture Congress, Ankara.

Kleiberit, 2006. PVAc D4 adhesive product technical catalog, Kleiberit product catalog, Germany, 1-3.

Leufenberg T., 1982. Exposure Effect Upon Performance of Laminated Veneer Lumber and Glulam Materials, Forest Products Journal, 32, 5.

Örs Y, Özçifçi A, Atar M., 1999. Bonding resistance of the Klebit 303, Kleiberit 305.0 and Süper-Lackleim 308 adhesives, Turkish Journal of Agriculture and Forestry, 23(3), 757-761.

Park Han-Min, Fushitani M, Sato K, Kubo T, Byeon HeeSeop, 2003. Static bending strength performances of cross-laminated woods made with five species, The Japan Wood Research Society, Japan, 49, 411-417.

Söğütlü C, Döngel N., 2007. Tensile shear strengths of some local woods bonded with polyvinyl acetate and 
polyurethane adhesives G.U. Faculty of Technical Education, Journal of Polytechnic, 10(3), 287-293.

Sönmez,A. Söğütlü,C. 2005. Rendeleme İşleminin Ağaç Malzeme Yüzey Pürüzlülüğüne Etkisi. Z.K.Ü. Teknik Eğitim Fakültesi, Teknoloji Dergisi, 8(3), 279-285.

TS EN 387, 2003. Glued laminated timber - Large finger joints - Performance requirements and minimum production requirements, TSE Standard, Ankara, 1-4.

Uysal, B., 2005. Bonding Strength and Dimentional Stabilityof Laminated Veneer Lumbers Manufactured Byusing Different Adhesives After The Steam Test, International Journal of Adhesion and Adhesives, 25, 395-403 